\title{
Narratives of the Nation in the Olympic Opening Ceremonies: Comparative Analysis of Beijing 2008 and London 2012
}

Professor Jongsoo Lee (Hanyang University, South Korea)

Dr. Hyunsun Yoon (University of East London, U.K.)*

\begin{abstract}
This paper examines the ways in which nationalism and the narratives of the nation were constructed in the Olympic opening ceremonies in Beijing 2008 and London 2012. The ritual of the opening ceremony represents a concentration of features, qualities and messages that combine the local and global, the culturally specific and universal, in a complex production. Using textual analysis of the telecast of the above two opening ceremonies, the study found that the Beijing 2008 opening ceremony used a grand narrative of progress, emphasizing the unified identity of Chineseness, while privileging the official narrative of the nation and one collective identity. In contrast, the London 2012 opening ceremony highlighted the fragmented but diversified identity of Britishness, transpiring social inclusivity, cultural hybridity and multiculturalism. This may be related to the rise of different type of nationalism in the context of increasing globalization. The Beijing opening ceremony represented the Sinocentric Chinese new nationalism, whereas the London 2012 counterpart, up to a point, highlighted civic-based multicultural nationalism.
\end{abstract}

KEYWORDS: narratives of the nation, nationalism, national identity, Olympic opening ceremony, globalization

*Corresponding author: Dr. Hyunsun Yoon (‥h.yoon@uel.ac.uk) 


\section{Introduction}

The Olympics is much more than a sporting event; it is a cultural phenomenon and a global spectacle. The opening ceremonies attract a global audience of billions. Over the years, Games organizers have managed to find creative ways to combine the Olympic protocol ${ }_{1}$ with the right amount of entertainment, cultural references, technological innovations and festive atmosphere (IOC 2014: 4).

De Coubertin's vision of the modern Olympics concentrated on artistic achievements as well as athletic competitions (De Coubertin 1997) and his ideals are most effectively manifested in the opening and closing ceremonies. 2 In particular, the artistic programmes in these ceremonies dramatize national myths, experiences, and values, focusing on such themes as the antiquity of the nation and the struggles, triumphs, courage, and character of its people (Hogan 2003: 104). Tomlinson and Young (2006: 3) have defined a global sporting spectacle as 'an event that has come to involve the majority of the nations of the world, that is transmitted globally, that foregrounds the sculptured and commodified body and orchestrates a physical display of the body politic, and that attracts large and regular followings of on-site spectators for the live contest or event'. What is presented in an Olympic ceremony needs to reach a universal audience in a simultaneous framework and to be easily transmitted and interpreted through the media (MacAloon 1996). And yet, according to Hogan (2009: 98), the consciously universalist rituals of the ceremonies are in a sense domesticated by the host nations and imbued with national meanings.

The ritual of the opening ceremony represents a concentration of features, qualities and messages that combine the local and global, the culturally specific and universal, in a complex production (Chen et al. 2012: 188). The ceremony tends to draw on the nation's culture to a great extent. The narrative in the Olympic opening ceremonies serves not only as an affirmation of national identity but also as an extended advertisement for the host nation and an opportunity to promote tourism, international corporate investment, trade, and political ideology (Hogan 2003: 102). It is through global mega-events like these Olympic Games, that national identity is reconstructed and sometimes recreated. The artistic programme in the opening ceremony stages national history and 
cultural identity in well-woven narratives to domestic and global audiences. Such representations constitute discourses of national identity or what Hall (1992: 293) has called the 'narrative of nation', which is 'a set of stories, images, landscapes, scenarios, historical events, national symbols and rituals that stand for the shared experiences, sorrows, and triumphs and disasters which give meaning to the nation'.

The aim of this paper is to examine the discourse on national identity in the Olympic opening ceremonies of Beijing 2008 and London 2012 by adopting a textual analysis of the telecast of the above events. 3 The rationale behind the choice of the two Olympic Games lies in the belief and assumption that these two most recent Olympic openings have shown significantly different narrative strategies to represent national histories and identities. The Olympic Games is a key site in the discursive construction of nation (Hogan 2003: 101). More recently, opening (and closing) ceremonies of the Olympic Games as a global media spectacle have become a vehicle for showcasing the national pride beyond the scope of redefining national identity. Beijing 2008 is a good case in point. The London Olympics opening ceremony seemed to attempt to find out the very 'different' narrative strategies from Beijing's to demonstrate their national identity. Then, what kind of narratives of the nation could be found in the making of the national identity of the 'Chineseness' and the 'Britishness' in these ceremonies? What kind of historical facts, national figures, and national symbols were recalled from the national 'past' to construct the present and, future of the nations? Using textual analysis, this study aims to illustrate how the narratives of nations are constructed through different historical narrative modes. Finally, this study discusses the socio-political implication of the different narratives of nations in relation to the changing concept of 'nations' and national identities in the context of globalization.

\section{Narratives of the nation in the age of globalization}

A variety of contemporary nationalism has emerged as a multifaceted phenomenon in the increasing multinational, globalizing context (Natalie 2010; Kramer 2011). The nation and nation-states can be defined as a symbolic, cultural construct as well as political entities. Hobsbawm (1992: 192) has 
emphasized the political core of nationalism, "once extracted like the mollusk from the apparently hard shell of the nation-state" emerges in distinctively wobbly shape. According to Smith (1991), nations have deep roots based on pre-political, cultural and ethnic identities. In this view, nationalism emerges primarily as a cultural doctrine, which seeks to preserve and promote identity, culture and autonomy of a nation. Indeed, Smith (1991: 74) has argued that nationalism is a "political ideology with a cultural doctrine at its centre". As Hall (1992: 355) has argued, the nation-state was never simply a political entity. It was always also a symbolic formation - a 'system of representation' which produced an idea of the nation as an 'imagined community', with whose meanings we could identify and which through this imaginary identification, constituted its citizens as 'subjects'. Whenever nationalism has evolved on the left-right political spectrum, however, it has always promoted selfconscious cultural identities.

Furthermore, Billig (1995) has argued that, in the established nations, there is a continual 'flagging', or reminding, of nationhood and that this reminding is so familiar, so continual, that it is not consciously registered as reminding. National identity, according to Billig (1995: 7-8), embraces all these forgotten reminders and therefore, an identity is to be found in the embodied habits of social life. In a similar vein, Edensor (2006) has argued that everyday life and habit are important to the reproduction of national identities. He has argued, rather than dominant linear depictions of the time of the nation, which have over-emphasized 'official' histories, tradition and heroic narratives, it is through the everyday rhythms that a sense of national belonging is sustained.

As a result of increasing globalization and transnational immigration, there has been a challenge to the concept of nation based on the homogeneous national culture and national identity. Bhabha (1994) has pointed out that the concept of nation as an 'imagined community' proposed by Benedict Anderson_(2006) was rooted in a 'homogeneous empty time' of modernity and progress. According to Bhabha (1994), the very concepts of homogeneous national cultures, the consensual or contiguous transmission of historical traditions, or 'organic' ethnic communities - as the grounds of cultural comparativism - are in a profound process of redefinition. There is overwhelming evidence of 
a more transnational and translational sense of hybridity of imagined communities (Bhabha 1994: 7). Increasingly, national cultures are being produced from the perspective of disenfranchised minorities.

\section{Global sporting spectacle as the site of national narrative}

Sport represents a domain where globalization is at its most advanced (Rowe 2011). Global spectacles are organized around sporting nations and yet, even here the nation is not overridden by the global. According to Rowe (2003), this is the paradox of what he referred to as 'sport's repudiation of the global' where globalization is conceived most strongly as producing global cultural homogeneity. Here, sport is unquestionably one of the most potent sources of vibrant, compressed national symbolism (Rowe 2012: 22). Furthermore, the importance of sporting mega-events has been recognized increasingly in a world of cultural and economic globalization (Roche 2000; Miller et al. 2001). Global sporting spectacles are, thus, phenomena where the process of globalization and the existing power of the nation-states intertwined and contested (Tomlinson 1999). Tomlinson and Young (2006) have said the Olympics and World Cup as media events have continued to stimulate fierce competitions among nations for the right to host sporting mega-events to fuel discourses and narratives of international competition and national rivalry. This is because, as MacAloon (1981) has identified, the interlocking cultural, political, and commercial interests that are the basis of the formation of the Olympics (and other sports mega-events) became stronger and stronger so that nations have become increasingly committed to the prospect of staging mega-events.

Global sporting events such as the Olympics provide interesting sites to examine how national identity is reconstructed and rearticulated and how new forms of nationalism are emerging. Especially, the performative segments of sporting spectacles have frequently been discussed as a potent space for conveying very particular or selected narratives of nation (Hall 1992) through viscerally effective processes of subject formation (Hogan 2003; Falcous and Silk 2010). In addition, the narratives of the nation are often explicit in national anthems and it is worth remembering that they feature frequently at sport mega-events. For a very long time, host nations have used these sporting mega-events to celebrate their historical legacy as well as to aspire to the expression of their 
modernity. The international profile of such media events has produced recurrent discourses of identity and globalization (Tomlinson and Young 2006: 3). For example, the Athens Olympics in 1896 was based on the reclamation of the classical past and in Uruguay in 1930 on the centennial celebration of its constitutional independence (Tomlinson and Young 2006: 5). The Los Angeles Olympic Games of 1984 was a watershed in the staging of the mega-sports event, providing spectacular opening and closing ceremonies to assert the superiority of the Western, capitalist, freeAmerican way over the oppressive Eastern, Communist, totalitarian Soviet way (Tomlinson 1999). Silk (2011: 735) has argued that since the 1984 Los Angeles Olympics, the Olympic Games are a correlative to consumer society that requires consumption and the appropriation of spectacle to reproduce itself. In this sense, the Olympic sporting mega-event is a part of the broad social forces that nurture and sustain a consumption economy, a seductive spectacle that fascinated the denizens of society (Kellner 2003 quoted in Silk 2011). More recently, Rowe and Stevenson (2006) have said that the Sydney Olympics in 2000 provided a probably unprecedented forum for appraising and accessing contemporary 'Australianess' with a key theme of reconciliation.

Sports mega-events are important constituents of an 'evolving global cultural economy' (Rowe 2003). One way that nation-states react to globalization is by intensifying existing national and ethnic divisions (Nicol and Townsend-Gault 2005). For example, during the 1990 Albertville Winter Olympics, against the backdrop of European flags reflected a "restoration of the national culture after gestures towards the regionally supranational (the EU) and the global (the Olympic phenomenon)" (Tomlinson 1996: 598; quoted in Housel 2007: 447). The other way is to use the Olympic spectacle to construct a new national identity such as multicultural, civic nationalism reflecting complicated national consciousness and anxieties. Dichotomy of civic and ethnic nationalism is an example of categories for nationalism and national identities that historians, since the early twentieth century, have been using in order to find broad historical patterns in political and cultural movements. The civic, political nation is theoretically open to newcomers because individuals can choose to join the civic nation, whereas the ethnic, linguistic nation is theoretically closed to outsiders because individuals are born into ethnic and linguistic communities. The older nationalist belief in coherent 
cultural nations had gradually lost credibility in the multicultural, democratic societies of contemporary Europe (Kramer 2011: 188). In this era of multicultural societies, modern states could actually achieve the greatest coherence by affirming the cultural diversity within their territories and then stressing that these diverse groups shared a commitment to democratic political progress. Given the increasing multiculturalism and multi-ethnicity of our societies, Leersen $(2006: 246,249,251)$ notes that the state should abandon its old nationality as its enabling principle and revert from the outworn ideal of the nation-state to that of the civic state. In a similar vein, Kramer (2011: 197) argues that the romantic aspiration for coherent nation-states that would embody the cultures of specific ethnic, linguistic, or religious group, for example, seems too narrow for complex, multicultural nations in which a shared commitment to civic values has gradually become the central component of nationhood.

Rowe (2003: 287) has argued that international sport can be a key marker of national fantasy or aspiration, but above all it is generative of a symbolic entity that comes into being by affixing a notion of identity that is likely to be an impediment of the free-floating cosmopolitanism so crucial to the ethos of globalization. National identity is constructed from the narratives of the nation, which consists of the collective memories, national symbols, and historical events shared by people of the specific nation. Then, how are narratives of national histories formed? Narrativism, in a nutshell, is the belief that no 'meaning' is inherent to a collection of historical facts and events retained or selected from the past. Rather, the act of narration is in itself responsible for any sense of meaning or causality that links historical events together (Berlatsky 2006). According to Stone (1981: 74), narrative means the organization of material into a chronologically sequential order. In Stone's definition, narrative functions as a structuring and ordering principle which excludes all events or information that do not fit into its 'coherent story'. By providing a sense of order and coherence, historical narrative produces the effects of having filled in all the gaps, of constructing desire (White 1987). White (1987) continues to argue that while both annals and historical narratives select certain events to include while omitting many others, narratives give the impression of a unified whole with no exclusions or erasures, in which the past makes sense and all events are connected. 
Bhabha (1990) emphasizes how nationalism involves a construction of linear narratives of nation, culture, and identity. In other words, this process of 'narrating the nation' occurs when people negotiate their relationships with a particular nation by constructing narrative that defines their boundaries (Housel 2007: 447). Using Bhabha's (1990) analysis of narratives of the nation, Danforth (2001: 363-364) discusses how such narratives often begin with the nation's 'birth', proceed through its 'coming of age', and end when it reaches 'maturity'. He explains that as the narrative gives significance, coherence and continuity to a series of events, the narrative consequently naturalizes certain constructions of reality as possessing meaning and truth. Narrativising a relationship between a "people" and a civic-territorial complex thereafter construed as "natural", national narratives effected imaginary relations between peoples and the states that secured them to their apparatuses (Peace 1997: 4). As collectively experienced fantasies, these narratives extended the reach of state regulatory mechanisms into the individual psyche where these fantasies have historically performed functions that are both extensive and complexly interrelated. Hall (1993: 355) argues that nationalism is mobilized by 'very different political positions, at different historical moments', while 'reflecting the traditions, discourses and forces with which it is articulated'. It is, therefore, important to examine the struggles over narratives of the nation and narrative strategies employed by different nations at different historical moments.

Based on the above discussion, we may propose using two distinct modes of historical narrative in further discussion: traditional and non-traditional modes. The traditional mode of historical narrative implies chronological progress, or movement forward in (explicitly) temporal and (implicitly) thematic fashion (Berlatsky 2006: 263). A traditional narrative then is comprised both of the desire for stability that is not realized in the long middle of a narrative and of the sufficiency that characterizes its ending. At the end of traditional narrative wherein desire is satisfied, the traditional mode of historical narrative usually suggests a kind of totalizing and unifying history. Non-traditional, or alternative, narrative mode transpires the sense of incoherence and fragmented reality itself. This shows a mixed account of history. Sometimes traumatic historical moments (conflicting views of the national history) and insecurity of national identities are presented. In Nietzsche, Genealogy, History, 
Foucault (1984) argues that 'classical' history attempts to represent history as unified and comprehensible. In doing so, it erases the past rather than preserving it and serves the needs of hegemony. Furthermore, Foucault argues for an alternative type of history which introduces discontinuity into our very being' (Foucault 1984: 88). In addition, non-traditional mode implies the possibility of the heterogeneity in historical views and goals. Historical discourse is sometimes involved with mixed messages and feelings and conflicting historical views; in other words, official and competing historical views coexist. The next section considers these points in more detail using the examples of the Beijing 2008 and London 2012 opening ceremonies.

\section{The rebirth of 'Great China': Coherent narrative of the unified China}

Beijing 2008 was opened by the film director Zhang Yimou's lavish ceremony.4 It began at 8.08pm on 8 August 2008, reflecting the belief in Asia that eight is a lucky number. With the announcement of the opening lines of The Analects of Confucius5 - 'Is it not delightful to have friends come from distant quarters?' - the ceremony presented China's glorious past with four great inventions that China gave to the world. Entitled 'The Beautiful Olympics', it was divided into two acts: 'Brilliant Civilization' and 'Glorious Age'. Three of the four great inventions of the pre-modern era were presented in the first act, encapsulating the country's 5,000 years of history. The second act was about the country's present and hopes for the future. It thus followed the monumental history that emphasized what the Chinese gave to the world and its economic prosperity of the present. This could be read as an attempt to privilege and to reinforce the official narrative of the nation. The narrative of 'New age of China' was constructed by connecting the glorious historical achievements to the present economic progress and the prospects of future global superpower. The capitalist and imperialist progress in consistent with traditional Western historical narrative was used to portray the long history of China in a coherent story. According to Askew (2009), the ceremony was a significant and symbolic demonstration of the determination to forge a place in the international community for China as a superpower. It announced the arrival of an emerging global power and sought to recreate the global narrative of China as the story of a forward-looking, modern nation that can boast a long 
and glorious past.

Gries (2004) argues that the Western view of the nation as a uniquely modern institution is problematic in the Chinese context because it has four millennia of documented history and two millennia of centralized rule. In addition, Confucian universalism holds that all peoples can become Chinese if they adapt to a Sinocentric civilization. According to Gries (2004), pride in the superiority of Confucian civilization is central to nationalism in China today and it seems that Confucianism does not "thin out" nationalism, but is instead the very basis of China's new nationalism. The idealized ethnic double-blind of Confucianism was on display, with two of the most prominent minority characters, the $15^{\text {th }} \mathrm{C}$ Hui Muslim admiral Zheng He and Zhuang-nationality gymnast Li Ning, as symbols of a more cosmopolitan Chineseness. The Silk Route and the Maritime Silk Route of Zheng He's famous sea voyages took center stage.

In order to construct the totalizing and unifying history of China, historical moments and events that might have recalled inherent narrative weakness and a sense of inferiority were deliberately excluded. According to Barmé (2009: 64), the directors of the opening ceremony created a "flattened" narrative that eliminated China's $20^{\text {th }}$ century history of radical iconoclasm and struggle, as well as democratic aspiration while pursuing the central theme of Communist Party policy, that of 'harmony'. The latter was described as 'the official narrative' by Askew (2009), and the former was 'the counter-narrative'. Askew (2009: 113) notes:

During the Games, the official narrative in which Beijing attempted to use the Games to construct a new national identity and to articulate its aspirations for a new world order in which Beijing will play an increasingly central role, and the counter-narrative which criticized China's human rights record, were both unveiled on the global stage.

The opening ceremony reflected the official narrative of the nation, in which a secure, confident and westernizing China demonstrated that it was both willing and able to rejoin the community of nations and seemed to confirm one understanding of China - that of a modern, sophisticated, and powerful 
nation with a glorious past. At the same time, however, the violence and bloodshed immediately preceding the Games lent support to the counter-narrative, confirming a very different understanding of the Chinese Party-State as a savage and brutal power, indifferent to human rights and contemptuous of its colonized people. In addition, Barmé (2009: 70) has argued that the Party wanted the ceremonies to be 'outstanding, innovative, employ local colour, reflect the spirit of the age and take an international perspective' One local media reported that the creative team had to use an international language to tell China's story (Heping 2008: 70). While understanding sport as a particularly lustrous and affective cultural form which constitutes part of what Stuart Hall (1992) termed 'narratives of nation', sporting discourses, practices and experiences have often been mobilized and appropriated by dominant groups to (re)define the parameters of the 'sanctioned' identity, as Tomlinson and Young (2006) have argued, and Beijing 2008 could be an example.

As many scholars such as Housel (2007) and Tomlinson (2005b) have found in their studies of the Olympic opening ceremonies, the attempts to construct a new nationhood and national identity reflect the paradoxes of nationalism in the context of postnationalism. Such tensions and competing narratives of the nation are pertinent to the globalization debate, which interrogates the nation's place when culture circulates within the global, national and subnational spheres (Housel 2007; 458). Many Chinese commentators noted that the Chinese story humped from bold dynastic achievement to a less than cogent spectacle of China today and tomorrow (Barmé 2009: 82). For decades, the struggles of modern China - foreign incursions, political collapse, natural disaster and poverty - have been the central feature of official history. In the opening ceremony, celebrating the best of the nation and focusing on the greatness of the nation, however, the story of modern China from the 1840s Opium War was entirely elided (Barmé 2009: 82). Rapid transformation, economic growth, political turbulence and contemporary life in modern China were all ignored.

Parts of China's modern history that is challenging the grand narrative of 'progress' to a New China were all excluded in the ceremony. They include the period from the Opium Wars through to 1949, followed by a long period of international isolation, the Anti-Rightist Campaign of 1957, the 
Great Leap Forward of 1958-1960, subsequent mass starvation, the Cultural Revolution of 1966 to 1969, the Tiananmen Square (June the Fourth) Massacre of 1989, together with the invasion and occupation of Tibet in 1950 and continuing human rights issues. Without understanding China's modern history, it is difficult to understand the ways in which the Beijing Olympic Games represent the self-image of a new China in the global extravaganza of the 2008 Games. Lovell (2008: 765) argues that "an unstable consciousness of ancient glory and modern humiliation will haunt contemporary China's self-image," and provides the context against which we must read the mixed messages of the Beijing Olympics - a metonym for the curious phenomenon of modern Chinese nationalism. In portraying the image of a new China, Beijing openings used Chinese traditional culture and values. The Confucian concepts of 'cosmopolitan ecumenism' striving for continual improvement and the 'harmony between man and nature' were in keeping with the Olympic movement's spirit of friendship, solidarity, and fair play and its motto 'faster, higher, stronger' (Leibold 2010: 21).6 This is the often-used narrative strategies in Olympic openings. Thus, the universal value of the Olympic ideal is reworked through the application of particular histories and cultures within the ceremonies of national culture and values (Tomlinson 1996: 590).

Children from ethnic minorities7 marched in traditional costumes, carried the PRC flag and sang, but they later turned out to be professional Han actors from the Galaxy Children's Art Troupe. This shows that the PRC's official discourse of multiculturalism conveys a sort of unity in diversity, but one might argue that behind Chinese multiculturalism lie deep fissures of Han ethnocentrism (Leibold 2010: 8). Despite the effort to present the unified, harmonious Chinese national identity, the division and dissents inevitably divulged. Tomlinson's (2005a: 83) analysis of the opening ceremonies of the 1998 Nagano and 2002 Salt Lake City Winter Games demonstrates how the "claimed universalism" of the Olympics can be appropriated into a particular nationalist cause and merged with a set of national values such as ambition and hard work. As such, the Olympic opening ceremonies provide spaces for rituals and performances of the "new national and ethnic demand" (Tomlinson and Young 2006: 588) in the face of uneven globalizing processes. 
All in all, the Beijing Games was hoped to function to announce the arrival of an emerging global power, and sought to recreate the global narrative of China as the story of a forward-looking, modern nation that can boast a long and glorious past (Askew 2009: 104). In doing so, a grand narrative of progress was used to construct the totalizing and unifying history of China whilst excluding the history of modern China.

\section{Reimagining 'Britishness': Hybrid narrative of the multicultural Britain}

In the British context, some recent studies on national identity such as Heath et al. (2006) and Fenton (2007) have found that there are uncertainties and anxieties over Britain's place in a post-colonial global order. They have also argued that it is difficult to define the Britishness and whether or not people take it seriously about their national identities. In this climate, film director Danny Boyle wanted to address "where were we [Britain], where have we come from, what is the heritage, what are we now and where are we going, and on that journey what are the values that we hold up as being valuable?" (Boyle 2012). The London 2012 opening ceremony, 'Isle of Wonder', highlighted the global advantages of diversity, harmony and multiculturalism (Falcous and Silk 2010). As observed by Manley and Silk (2014: 367), Boyle contemplated the gendered, raced and classed 'problems' across Britain during the Industrial Revolution and the ability of working people through trade unionism and protest' to locate Britain as the 'workshop of the world'. Main sections of the artistic display at London 2012 were about the country's Industrial Revolution, literary heritage, popular culture and National Health Service (NHS). The emphasis on literary fantasy, in particular, provided Boyle with an escape from Britain through parody and a means for negotiating changed conceptions of Britishness (Savage et al. 2010). For example, the darkness of Lord Voldemort (from the Harry Potter novels) was the antithesis of the idealized Anglocised history and landscape within children's literature. British popular music and culture was also celebrated: Frankie and June was emblematic of a 'pure politics' that asserted a mythic, inclusive 'multiculturalist nationalism' and tolerance which necessitated "interpolating others" to be seen to speak out as proud subjects of multicultural [British] (Fortier 2005: 562). 
A rural scene with the model of Glastonbury Tor opened the ceremony and youth choirs, from different parts of the country, sang four songs representing the four nations of the UK (Jerusalem for England, Danny Boy for Northern Ireland, Flower of Scotland for the Scotland and Bread of Heaven for Wales), encapsulating the ideals of togetherness across counties within the UK. Based on the notions of 'integration', 'respect for British values and way of life' and the building of a single nation (Davis 2005 in Yousuf 2007), the reimagined idea of Britishness posits shared values as opposed to colour or unchangeable institutions as defining a contemporary civic identity (Gordon Brown 2005 in Yousuf 2007). Indeed as argued by Stuart Hall (1993), the history of the nation-states of the West has never been this ethnically pure and they have always been ethnically hybrid. The main function of national cultures is to represent what is in fact the ethnic hotch-potch of modern nationality as the primordial unity of 'one people' and of their invented traditions to project the ruptures and conquests, which are their real history, backwards in an apparently seamless and unbroken continuity towards pure, mythic time (Hall 1993: 356).

While the grand narrative of progress once provided communal identity and reassurance to the hegemonic interests of Britain, sometimes Britain on the world stage, with its lost history, becomes pointless information with no practical relevance to today's real world. This could be related to the act of critical deconstruction (Berlastsky 2006: 263). With the dissolution of the Empire, the totalizing narrative of progress was also dismantled. London 2012 provided a unique opportunity to show off a new British identity in the post-imperial age. It was a portrait of Britain that has gone through a great deal of changes since its last Olympic Games in 1948. Britain changed the terrain of the discourses on the national identity, not in its economic and political dominance, but in its cultural power. The London opening alluded to Western cultural hegemony, especially the power of British popular culture since the Second World War. While Beijing 2008 focused on traditional culture and ancient history, London 2012 did not include ancient British history. Instead, it focused on modernization and contemporary pop culture. Writing in 2011, Silk (2011: 739) predicted that following previous work on sporting spectacle, it is likely that the deployment of selective histories for use in the present will be a central component of the 'cultural presentation' segments of the 
London 2012 opening ceremony.

Unlike Beijing, the London 2012 opening ceremony had a sense of humour. The entry of the Queen with James Bond and the Mr. Bean character (Rowan Atkinson) were good examples. Quintessentially British, anarchic spirit and their ability to laugh at themselves were evident in the ceremony. Barmé (2009) has argued that Beijing's ceremony had the grandiose, breathtaking order with intimidating precision and scale. By contrast, London 2012 had an individualistic, creative and chaotic energy, and the sense of humour.

Ethnic diversity was explicitly shown and embraced in a number of performances including the scene of the hymn 'Abide by Me' sung by Emeli Sande, who is Scottish, with a contemporary dance choreographed by Akram Khan, an English dancer/choreographer of Bangladeshi descent. Thus, race is discursively produced in the material and symbolic landscapes of London 2012 (Manley and Silk 2014: 366). Housel (2007: 447) provides an interesting case study that the Sydney Olympics opening ceremony presented the narrative of a united Australian nation and how it responds to the increasing disintegration of nation-states' boundaries in the context of globalization. After all, diversity was a key reason why London, one of the most multicultural cities in the world, was chosen to host the 2012 Games. The inclusive tone of the narratives in the London opening ceremony was much celebrated. This was not about portraying the neo-imperial, neo-colonial, neo-nationalistic age but about a post-imperial, post-colonial, post-nationalistic age. The national narrative in the London 2012 opening emphasized the ordinary people's experiences and the values of civil society. 8 Complexity flows around borders, cultural hybridity, and the disintegration of rigid national borders are all characteristics of the global condition and the narrative of the nation is imbued by constantly shifting meanings and definitions which are assigned to categories such as 'ethnic', 'national' and 'multicultural'.

\section{Differences in narratives of the nation in Beijing and London openings}

Hall (1990) associates the narratives of the past as essential to better come to terms with identity 
formation. In particular, his theorization of the intricate working between the past and the present offers an insight into the understanding of postcolonial consciousness (Oh 2009: 374). According to Hall (1990: 225-226), cultural identities are 'the points of identification', which are made, within the discourses of history and culture. In other words, cultural identities are shaped by the narratives of the past which is constructed through 'memory, fantasy, narrative and myth'. In the Olympic opening ceremonies, China and Britain constructed their national histories in quite different narrative modes. The Beijing opening employed the traditional narrative mode in which the glorious ancient Chinese culture was connected to the 'New China' - a global superpower (surpassing the Western dominance) - in a very coherent story of 'progress'. On the other hand, the London opening took a non-traditional, alternative narrative mode, which no attempt to emphasize their imperial past. Instead, it was made up of rather fragmented and heterogeneous historical events and memories intermingled, almost showcasing what Brits themselves deemed to be their finest contributions to the world's history. In other words, it was a hybrid form of real historical fact and fictional/symbolic figures. The following table (Table 1.) summarizes these findings.

Table 1. Differences in narratives of the nation

\begin{tabular}{|c|c|c|}
\hline & $\begin{array}{l}\text { Beijing } 2008 \\
\text { Traditional narrative }\end{array}$ & $\begin{array}{l}\text { London } 2012 \\
\text { Non-traditional narrative }\end{array}$ \\
\hline $\begin{array}{l}\text { Narrative of unity vs. the } \\
\text { fragmented }\end{array}$ & $\begin{array}{l}\text { - Totalizing and unifying } \\
\text { history (narrative of } \\
\text { homogeneity and } \\
\text { unity) } \\
\text { - Narrative of progress } \\
\text { and explicit national } \\
\text { goals }\end{array}$ & $\begin{array}{l}\text { - } \text { Fragmented and } \\
\text { competing histories } \\
\text { (narrative of } \\
\text { heterogeneity) } \\
\text { - Narrative of democracy } \\
\text { and implicit national } \\
\text { value }\end{array}$ \\
\hline
\end{tabular}




\begin{tabular}{|c|c|c|c|}
\hline Time span & - & $\begin{array}{l}\text { Ancient-present-future } \\
\text { (grand narrative) } \\
\text { Exclusion of modern } \\
\text { Chinese history } \\
\text { The glorious past } \\
\text { connecting to the future } \\
\text { superpower }\end{array}$ & $\begin{array}{l}\text { - Industrial revolution- } \\
\text { the present (the } \\
\text { 'shadowed' present) } \\
\text { - Exclusion of the past } \\
\text { imperial age }\end{array}$ \\
\hline Space boundary & - & $\begin{array}{l}\text { Expanding China to the } \\
\text { global and the universe } \\
\text { Neo-imperial age }\end{array}$ & $\begin{array}{ll}\text { - } & \text { Britain centric } \\
\text { - } & \text { Post-imperial age }\end{array}$ \\
\hline Expressive level & - & $\begin{array}{l}\text { Linear and orderly } \\
\text { progress } \\
\text { Well-disciplined mass } \\
\text { performance }\end{array}$ & $\begin{array}{l}\text { - } \text { Chaotic expression } \\
\text { - } \quad \text { Free, individual } \\
\text { expression }\end{array}$ \\
\hline $\begin{array}{l}\text { National values: } \\
\text { Collectivism vs. individualism }\end{array}$ & - & $\begin{array}{l}\text { Collective self- } \\
\text { effacement } \\
\text { Heated patriotism } \\
\text { Chinese nationalism }\end{array}$ & $\begin{array}{ll}- & \text { Individualism } \\
\text { - } & \text { Detachment } \\
\text { - } & \text { Cool patriotism } \\
\text { - } & \text { Britishness (satire and } \\
& \text { humour) }\end{array}$ \\
\hline
\end{tabular}

Compiled by the authors.

In the increasing globalization and postnational context, the once hegemonic narrative of the nation has been challenged and transformed. As Bhabha $(1990,1994)$ explained, no fixed boundaries of the national identity and one coherent national narrative exist. The competing narratives of the nation are contested in the terrain of global media events such as Olympic ceremonies. However, in the Beijing opening ceremony, one collective identity and national goal was emphasized, privileging 
the official narrative of the nation. It represents 'modern Chinese nationalism' and a new nationalist move in the postnational age. On the other hand, the London opening had the hybrid narratives of the nation, representing the British model of postnationalism that Koopmans and Statham (1999) have described. Regarding migrants and postnational membership in Europe, Soysal (1994) presented important evidences on cross-national differences in migrant and minority mobilization in different European countries. To explain these differences, she points out, much along the lines of argument here, at the different traditions and institutional arrangements of migrant incorporation in these countries. In that sense, Soysal's empirical analyses, which point at the importance of national contexts, are strangely at odds with her main theoretical conclusions, which emphasize the irrelevance of national compared to postnational forms of citizenship.

One could argue that while the Chinese national narrative was 'ethnocultural exclusionist', the British narrative was more 'multicultural pluralist'. While the Chinese mode of historical narrative put emphasis on the nationalist pride and feelings, the British model provided much easier access to citizenship, and furthermore, it gave limited but still substantial recognition to their cultural differences. The British model of migrant incorporation is, to a great extent, a consequence of its imperial, colonial past, and by way of several restrictive changes in citizenship legislation, subsequent British government have done much to limit these consequences. In the London opening, there was a sense of the ambiguities in British identity. All identities, including a British identity, are more situational and negotiated than the 'essentialist' appears to understand and the other cannot be separated from the self (Cohen 1994: 581).

\section{Conclusion}

This paper has examined how the narrative of nation is constructed in the performative segments of the Beijing and London Olympic opening ceremonies, which is one of the most important global media spectacles. This study has also tried to investigate the complicated process in which the different national motives and imperatives are intermeshed with the global mega sports events. Nationalism is mobilized by very different political positions, at different historical moments, 
reflecting the traditions, discourses and forces with which it is articulated (Hall 1993: 355). Differences in the narratives of the nation between the Beijing and London opening ceremonies show how the national identities are constantly reconstructed and reimagined through global media-sport spectacles like the Olympic openings. They also demonstrate how the unified or diversified version of national historical narrative responds to the increasing disintegration of nation-states' boundaries in the context of globalization. The Beijing 2008 opening used a grand narrative of 'progress', serving the national goal of global superpower with cultural legitimacy, while privileging the official narrative of the nation and one collective identity. It represented the images of a linear, orderly constructed historical narrative emphasizing the greatness and the centrality of China in the world. On the other hand, the London 2012 opening did not pursue the totalizing and unifying narrative of the nation. Instead, through satire and humour, the new national British identities and pride expressed conflicting historical views. By showing the adversity of working class people, the narrative of national history in the London opening rejects an illusionary wholeness and completeness.

The narratives of nations were constructed with different modes and sensibilities. As Smith (1991) has argued, any nation in the modern world represents a sometimes uneasy but necessary symbiosis of ethnic and civic elements. Also, the privileging narrative of nation to a certain extent would be challenged and negotiated as new forms of nationalism are emerging in the increasing globalization context. The Beijing opening emphasized the unified identity of Chineseness, the peaceful rise of Great China, transpiring a new Chinese nationalism which is Sinocentric and ethnicbased. On the other hand, the London opening highlighted the diversified identity of Britishness, conveying social inclusiveness, cultural hybridity and civic-based multi-cultural nationalism up to a point. The contrasting emphasis on the national identity and nationalism shown in the Beijing and London Olympic ceremonies has further implication that many-faced nationalism would be mobilized in the upcoming global sport spectacles. 


\section{References}

Anderson, B. 2006. Imagined Communities: Reflections on the Origin and Spread of Nationalism. $2^{\text {nd }}$ ed. rev. London: Verso.

Askew, D. 2009. 'Sport and Politics: The 2008 Beijing Olympic Games’, European Studies 127: 103120.

Barmé, G. R. 2009. 'China's Flat Earth: History and 8 August 2008', The China Quarterly 197: 64-86.

Berlatsky, E. 2006. 'The Swamps of Myth... and Empirical Fishing Lines: Historiography, Narrativity, and the "Here and Now" in Graham Swift's Waterland', Journal of Narrative Theory 36, 2: 254-292.

Bhabha, H. K. 1990. Nation and Narration. London: Routledge.

Bhabha, H. K. 1994. The Location of Culture. London: Routledge.

Billig, M. 1995. Banal Nationalism. London: Sage.

Boyle, D. 2012. 'Boyle Reveals Opening Ceremony', The Daily Telegraph. 12 June 2012.

Chen, C. C., Colapinto, C. and Luo, Q. 2012. 'The 2008 Beijing Olympics opening ceremony: Visual insights into China's soft power', Visual Studies 27, 2: 188-195.

Cohen, R. 1994. Frontiers of Identity; The British and the Others. London and New York: Longman.

Danforth, L. M. 2001. 'Is the "world game" an "ethnic game" or an "Aussie game"? Narrating the nation in Australian soccer', American Ethnologist 28, 2: 363-387.

De Courbertin, P. 1997. Olympic Memoirs. Reprint. Lausanne: International Olympic Committee.

Edensor, T. 2006. 'Reconsidering National Temporalities: Institutional Times, Everyday Routines, Serial Spaces and Synchronicities,' European Journal of Social Theory 9, 4: 525-545.

Falcous, M and Silk, M. 2010. 'Olympic Bidding, Multicultural Nationalism, Terror and the Epistemological Violence of Making Britain Proud', Studies in Ethnicity and Nationalism 10, 2: 167- 
186.

Fenton, S. 2007. 'Indifference toward national identity; what young adults think about being English and British,' Nations and Nationalism. 13, 2: 321-339.

Fortier, A. 2005. 'Pride Politics and Multiculturalist Citizenship', Ethnic and Racial Studies 28, 3 : $559-578$

Foucault, M. 1984. 'Nietzche, Genealogy, History' in P. Rainbow (ed), The Foucault Reader. New York: Pantheon Books.

Falcous, M. and Silk, M. 2010. 'Olympic Bidding, Multicultural Nationalism, Terror, and the Epistemological Violence of Making Britain Proud', Studies in Ethnicity and Nationalism. 10, 2: 167186.

Girginov, V. 2008. 'Creative tensions: 'Join in London' meets 'Dancing Beijing' - The cultural power of the Olympics', The International Journal of the History of Sport 25, 7: 893-914.

Gries, P. H. 2004. China's New Nationalism: Pride, Politics and Diplomacy. Berkeley and London: University of California Press.

Hall, S. 1990. 'Cultural Identity and Diaspora' in Rutherford, J. (ed) Identity: Community, Culture, Difference. London: Lawrence \& Wishart.

Hall, S. 1992. 'Cultural Studies and Its Theoretical Legacies' in L. Grossberg, C. Nelson and P. Treichler (eds.), Cultural Studies. London: Routledge.

Hall, S. 1993. 'Culture, community, nation', Cultural Studies 7, 3: 349-363.

Heath, A. Rothon, C. and Andersen, R. 2006 'Who feels British?' J. Curtice (ed) The Diversity of Devolution. Manchester: Manchester University Press.

Heping, S. 2008. 'Zhang Heping: using an international language to tell China's story', 
Sanlian Life Weekly. 18 August 2008: 68-71.

Hobsbawm, E. 1992. Nations and Nationalism since 1780. 2nd ed. Cambridge: Cambridge University Press.

Hogan, J. 2003. 'Staging the nation: Gendered and ethnicized discourses of national identity in Olympic opening ceremonies', Journal of Sport and Social Issues 27, 2: 100-123.

Hogan, J. 2009. Gender, Race and National Identity. New York and Abingdon: Routledge.

Housel, T. H. 2007. 'Australian nationalism and globalization: Narratives of the nation in the 2000 Sydney Olympics’ opening ceremony', Critical Studies in Mass Communication 24, 5: 446-461.

International Olympic Committee. 2014. Factsheet: Opening Ceremony of the Games of the Olympiad. Update - October.

Kellner, D. 2003. Media culture: Cultural studies, identity and politics between the modern and the post-modern. London and New York: Routledge.

Koopmans, R. and Statham, P. 1999. 'Challenging the liberal nation-state postnationalism, multiculturalism, and the collective claims making of migrants and ethnic minorities in Britain and Germany', American Journal of Sociology 105: 652-696.

Kramer, L. 2011. Nationalism in Europe and America: Politics, Cultures and Identities since 1773. Chapel Hill: University of North California Press.

Lattipongpun, W. 2010. 'The Origins of the Olympic Games' opening and closing ceremonies: Artistic Creativity and communication', Intercultural Communication Studies XIX: 103-120. Leersen, J. 2006. National Thought in Europe: A Cultural History. Amsterdam: Amsterdam University Press.

Leibold, J. 2010. 'The Beijing Olympics and China's conflicted national form', The China Journal 63: $1-24$. 
Lovell, J. 2008. 'Beijing 2008: The mixed messages of contemporary Chinese nationalism', The International Journal of the History of Sport 27, 7: 758-778.

MacAloon, J. 1981. 'This Great Symbol Pierre de Coubertin and the Origins of the Modern Olympic Games,' Monograph Collection, [Accessed on $31^{\text {st }}$ January 2017 at:

www.philpapers.org/rec/MACTGS-2]

MacAloon, J. 1996. Olympic ceremonies as a setting for intercultural exchange. In M. Moragas, J. MacAloon, and M. Llinés (eds.) Olympic ceremonies: historical continuity and cultural exchange. Barcelona: Centre d'Estudis Olímpics i de I'Esport, Universitat Autònoma de Barcelona, 29-44.

Manley, A. and Silk, M. 2014. 'Liquid London: Sporting spectacle, Britishness and Banoptic surveillance', Surveillance \& Society 11, 4: 360-376.

Miller, T., Lawrence, G., McKay, J. and Rowe, D. 2001. Globalization and Sport: Playing the World. London: Sage.

Natalie, S. 2010. Globalization and Nationalism: The Cases of Georgia and the Basque Country. Budapest and New York: Central European University Press.

Nicol, H. and Towsend-Gault, I. (eds.). 2005. Holding the Line: Borders in a Global World. Vancouver: University of British Columbia Press.

Oh, M.Y. 2009. 'Eternal Other’ Japan: South Koreans’ postcolonial identity’, The International Journal of the History of Sport 26, 3: 371-389.

Pease, D. E. 1997. 'National and Postnational Narrative', Modern Fiction Studies 43, 1: 1-23.

Roche, M. 2000. Mega-Events and Modernity: Olympics and Expos in the Growth of Global Culture, London and New York: Routledge.

Rowe, D. 2003. 'Sport and the repudiation of the global', International Review for the Sociology of Sport 38, 3: 281-294. 
Rowe, D. 2011. Global Media Sport: Flows, Forms and Futures. London: Bloomsbury Academic.

Rowe, D. 2012. 'Reflections on Communication and Sport: On Nation and Globalization', Communication and Sport 1, 2: 18-29.

Rowe, D. and Stevenson, D. 2006. 'Sociality and Spatiality in Global Media Events,' Tomlinson and Young (eds) National Identity and Global Sports Events: Culture, Politics, and Spectacle in the Olympics and the Football World Cup, New York: State University of New York Press.

Savage, M., Wright, D. and Gayo-Cal, M. 2010. 'Cosmopolitan Nationalism and the Cultural Reach of the White British', Nations and Nationalism 16, 4: 598-615.

Silk, M. 2011. 'Towards a sociological analysis of London 2012', Sociology 45, 5: 733-748.

Smith, A. D. 1991. National Identity. Reno and Las Vegas: University of Nevada Press.

Soysal, Y. N. 1994. Limits of citizenship: Migrants and postnational membership in Europe. Chicago and London: University of Chicago Press.

Stone, L. 1981. The Past and Present. Boston and London: Routledge.

The Guardian. 2012. 'Ai Weiwei: It was about real people'. 29 July.

Tomlinson, A. 1996. 'Olympic spectacle: Opening ceremonies and some paradoxes of globalization', Media, Culture \& Society 18: 583-602.

Tomlinson, A. 1999. 'Staging the Spectacle: Reflections of Olympic and World Cup Ceremonies,' Soundings 13: 1-12.

Tomlinson, A. 2005a. 'Picturing the Winter Olympics: The opening ceremonies of Nagano (Japan) 1988 and Salt Lake City (USA) 2002,' Tourism, Culture \& Communication 5, 2: 83-92.

Tomlinson, A. 2005b. 'Magnificent trivia: Olympic spectacle, opening ceremonies, and some paradoxes of globalization' in A. Tomlinson, Sport and Leisure Cultures. Minneapolis: University of 
Minnesota Press.

Tomlinson, A. and Young, C. 2006. National Identity and Global Sports Events: Culture, Politics, and Spectacle in the Olympics and the Football World Cup. New York: State University of New York Press.

White, H. 1987. The Content of the Form. Baltimore: John Hopkins University Press.

Yousuf, Z. 2007. 'Unravelling identities: Citizenship and legitimacy in a multicultural Britain', European Journal of Cultural Studies 10, 3: 360-373. 


\section{Notes}

1 Rule 55 of the Olympic Charter outlines the protocol that must be observed at the opening ceremony of the Games, of which important features are as follows: entry by the head of state; playing the national anthem; the parade of the athletes; the symbolic release of pigeons; the opening of the Games by the head of state; raising the Olympic flag and playing the Olympic anthem; the taking of the Olympic oath by an athlete; the taking of the Olympic oath by an official; the taking of the Olympic oath by a coach; the Olympic flame and Torch Relay; and the artistic programme (IOC, 2014: 1).

2 The Olympic Games' opening and closing ceremonies were initiated after the advisory conference in 1906 organized by De Courbetin through his artistic vision and this transformed the Olympic ritual in the modern era in the sense that these ceremonies have become the most important elements of the Olympics (Lattipongpun 2010: 103, 117).

3 Existing literature on comparative analysis of Beijing 2008 and London 2012 includes Girginov's study (2008) on emblems whereby the author argues Beijing's emblem ('Dancing Beijing') is a static image whereas London's counterpart ('Join in London') is a dynamic one. Both emblems represent core cultural values of two civilizations: the former epitomizes the Eastern way of thinking and conveys the unique cultural quality and elegance of Chinese civilization, while the latter has been designed to inspire youth and reflects the multicultural nature of British society (Girginov 2008: 893). Few studies considered the narratives of the nation in the opening ceremonies in the comparative context and this study intends to fill this lacuna.

4 Ai Weiwei, in reviewing the London 2012 opening ceremony and in reflecting the Beijing counterpart, stated that "Beijing's Olympics were very grand -they were trying to throw a party for the world, but the hosts didn't enjoy it. The government didn't care about people's feelings because it was trying to create an image."(The Guardian, 29th July 2012)

5 In recent years Confucius has been restored as a moral exemplar emblematic of service to the state and respect for hierarchical authority, and hence lending traditional weight to the party-state's watchword of social stability (Barmé 2009: 77). The army of Confucian disciples uses the bamboo-slip scrolls they hold to punctuate their chanting and as their performance comes to an end they give way to an undulating rectangle of "type-face blocks"(huozimo).

6 It is argued that while the two previous Asian hosts of the Olympics, Tokyo (1964) and Seoul (1988), used the games to secure the recognition of Japan and South Korea by the international community, China has a more ambitious agenda. Its proclaimed intent ostensibly is to reinterpret the fundamental Olympic principles by challenging the established Western ontology and norms of sport and 'to promote the harmonization of world civilizations'.

7 There are 56 ethnic groups in China; the largest ethnic group, Han, constitute about $91.9 \%$ of the population, according to a 2005 survey. Zhuang, Manchu and Hui are the ethnic groups that have over 10 million population, followed by Miao, Uyghur, Yi, Tujia, Mongols, Tibetans and so on. The status and the degree of assimilation and integration of ethnic minorities with the mainstream society vary from group to group but often the Han's attitudes toward ethnic minorities have not been welcomed nor favoured.

8 While London itself might demonstrate elements of post-nationalism and post-imperialism, this does not necessary mean that it holds true for the UK as a whole and in particular, for the other parts of England. 


\section{Biographical notes:}

Professor Jongsoo Lee

Address:

Department of Journalism and Mass Communication, College of Communication, Hanyang University ERICA campus, 55 Hanyangdaehak-ro, Sangnok-gu, Gyeonggi-do, 426-791. South Korea

Email: jslee77@hanyang.ac.kr

Professor Jongsoo Lee has BA (Hons) in English Literature (Ewha Women's University, South Korea), MA and Ph.D. in Journalism and Communication (University of Minnesota, USA). She has been teaching at the Department of Journalism and Mass Communication at Hanyang University in South Korea since 1997. She was President of Korean Women's Communication Association in 2010-11 and Dean of the College of Communication at Hanyang University in 2011-13. She has also been on the Editorial Board for Korean Journal of Communication \& Information and Media, Gender \& Culture.

Corresponding author:

Dr. Hyunsun Yoon

Address:

School of Art and Digital Industries, University of East London, 4-6 University Way, London, E16 2RD, UK.

Email: c.h.yoon@uel.ac.uk

Dr. Hyunsun Yoon has BA (Hons) in English Literature (Ewha Women's University, South Korea), MA in Journalism (Cardiff University, UK) and Ph.D. in Advertising (Cardiff University, UK). She has been teaching media and advertising at University of East London since 2005. As a Senior Lecturer and the Fellow of the Higher Education Academy, she has contributed chapters and published articles on sports media, theory and practice in advertising and representation. 